\title{
Od teatra do obreda: obredno prevrednovanje dramske izvedbe na primjeru misionarskog kazališta u Meksiku u 16. stoljeću
}

\author{
IVANA KRPAN \\ Filozofski fakultet Sveučilišta u Zagrebu
}

\begin{abstract}
Analizom dvaju običaja izvedbe misionarskih dramskih djela objašnjava se proces obrednog prevrednovanja španjolskog crkvenog prikazanja u evangelizaciji autohtonog stanovništva današnjeg Meksika u 16. stoljeću. Prikazanja su prvotno služila kao slikovit prikaz kršćanske doktrine novim vjernicima, ali je njihova uklopljenost u euharistijsko slavlje i primanje kršćanskih sakramenata poput krštenja i pričesti drami pridavala sakralno i obredno značenje. Primjeri takve prakse su prikazani analizom dramatizacije i istodobne obredne realizacije, odnosno "obredizacije" dramskog prikaza Bogojavljenja i običaja izvedbe bitaka Maura i kršćana u sklopu evangelizacijske kazališne metode. Na temelju antropoloških istraživanja izvedbenih svojstava obreda i njegove liminalnosti u procesu stvaranja novih društvenih i vjerskih struktura, opisan je učinak takve dramsko-obredne sinergije u oblikovanje vjerskog identiteta indijanskih obraćenika.
\end{abstract}

Ključne riječi: obredno prevrednovanje drame, misionarsko kazalište, Meksiko, evangelizacija

\section{KAZALIŠNO U OBREDNOM}

Termin misionarskog ili evangelizacijskog kazališta obuhvaća dramske tekstove i izvedbe kojima su u prvim desetljećima evangelizacije misionari pojašnjavali dijelove Evanđelja i podučavali indijansko stanovništvo osnovama kršćanskog vjerovanja i običaja uz pomoć dramskog prikaza Ono je u šesnaestostoljetnom Meksiku, tadašnjoj Novoj Španjolskoj, bilo jedinstven primjer obrednog ${ }^{1}$ prevrednovanja tradicionalnoga španjolskog crkvenog

\footnotetext{
${ }^{1} \mathrm{U}$ istraživanju indijanske izvedbene tradicije i kršćanskih svetkovina Nove Španjolske te pri prijevodu strane terminologije na hrvatski jezik, odlučujem se za razlikovanje pojmova "obreda" od "rituala" jer u studijama iste tematike na španjolskom jeziku nailazim na takav postupak, a smatram da se može opravdati i u hrvatskome jeziku, kako ću prikazati u nastavku bilješke. Na početku ipak valja upozoriti
} 


\section{prikazanja u okviru evangelizacije. Nastali po uzoru na srednjovjekovne kazališno-didaktične vrste, dramski su se tekstovi koristili kao predlošci za izvedbu nabožnih djela u sklopu javnih crkvenih ceremonija povodom blag- dana ili važnih političkih događaja u kolonijalnom Meksiku. Način dramati- zacije biblijskoga teksta i odabir tematskih cjelina nisu se znatnije razlikovali od španjolskog modela. Međutim, osobitost njihove izvedbe odredio je nov kontekst izvođenja u kojem je crkveno prikazanje kao dramska okosnica vjerskog slavlja postajalo dijelom euharistije i ostalih obreda u procesu kri-}

da se antropologija i teorija izvedbenih umjetnosti još uvijek nisu usuglasile oko točnog tumačenja navedenih pojmova niti oko potrebe za njihovim razlikovanjem te se često koriste proizvoljno, ponekad kao sinonimi ili se pak autori odlučuju za samo jedan naziv, češće ritual, te ga koriste kao označitelja obaju pojmova. Primjerice, u Pavisovom Pojmovniku teatra nalazimo samo pojam ritual (franc. rituel), dok za riječ obred (franc. rite) ne postoji zasebna definicija, već se u tumačenju rituala slobodno rabi kao njegova istoznačnica (Pavis 1987). Nadalje, Arnold van Gennep u djelu Obredi prijelaza, jednom od temeljnih istraživanja na koje se pozivaju današnje antropološke studije, pojmom obreda određuje ceremonije vezane uz prijelazna razdoblja u ljudskom životu poput rođenja, ženidbe ili smrti (van Gennep 1909), pa ipak, kasnija teorijska i antropološka istraživanja izvedbenih umjetnosti koja referiraju na van Gennepovu studiju, njegov pojam obreda (engl. rite) nerijetko preimenuju u ritual (engl. ritual) kojim označavaju različite oblike društvenog i vjerskog ritualiziranog ponašanja (Schechner 2006: 50; Turner 1982; Turner 1997). Isto tako, u hrvatskom prijevodu jednog od najznačajnijih radova na području kazališne antropologije, djelu Od rituala do teatra Victora Turnera, pojam rituala nerijetko se bez objašnjenja zamjenjuje riječju obred (Turner 1989: 188) i rabi kao njegova istoznačnica. Doprinos toj problematici nalazim u recentnijim istraživanjima poput djela Ritual Criticism Ronalda L. Grimesa, u kojem se upućuje na potrebu razlikovanja termina obred kao "specifičnog djelovanja u određenim vremenskim i prostornim okolnostima" koje se odnosi na konkretne događaje poput obreda krštenja, u odnosu na ritual kojim opisuje "općenito poimanje djelovanja u kojem obred ima istaknuto mjesto", odnosno teorijski termin koji obuhvaća i opisuje radnje vezane uz izvršenje obreda (Grimes 2014: 7). U etnološkoj i antropološkoj terminologiji na hrvatskom jeziku Ivan Lozica izdvaja termin obreda od običaja kao riječi koja bi bila bliska značenju rituala u stranim jezicima (Lozica 1990). S druge strane, u jezičnim rječnicima, i hrvatskog i stranih jezika, nalazimo preciznije razlikovanje tih pojmova. U Hrvatskom općem leksikonu pojam obreda definira se kao "1. Svaka svečana radnja prema točno propisanim i ustaljenim pravilima; temeljno mu je obilježje simboličko značenje; 2 . Ustaljene geste, čini i verbalni obrasci kojima čovjek odražava svoj odnos prema svetom, u kršćanstvu se upotrebljava u sakramentima, liturgiji te u pučkoj izvanliturgijskoj pobožnosti", dok za pojam ritual nalazimo "obred, obrednik: liturgijska knjiga obrednih tekstova za slavlja sakramenata i blagoslovina" (Domijan 2012). U hrvatskom Leksikonu ikonografije, liturgike i simbolike zapadnog kršćanstva ne nalazimo opis riječi ritual, no iz tumačenja ostalih pojmova se dade uočiti da se obred veže uz crkvene ceremonije i kršćanske sakramente (Badurina 1979). Španjolski (kao i ostali romanski) i engleski jezični rječnici razlikuju značenje rituala od obreda, pri čemu prvi označava "skupinu obreda neke religije, crkve ili svete ceremonije" (Diccionario de la lengua española de la Real Academia Española 2014) ili "svečanu vjersku ceremoniju koja se sastoji od niza radnji izvedenih prema zadanom i ustaljenom redoslijedu" i "niz radnji ili oblika ustaljenog i nepromjenjivog načina ponašanja" (Oxford Dictionary Online 2014). Obredom određuju "skup utvrđenih pravila u izvođenju kulta ili vjerske ceremonije" (Diccionario de la lengua española de la Real Academia Española 2014) ili “vjersku i svaku drugu svečanu ceremoniju ili čin" (Oxford Dictionary Online 2014). Temeljem priloženih odredbi zaključujem da bi termin obreda u hrvatskom jeziku valjalo rabiti kao riječ kojom se u užem smislu opisuju pravila pojedinačnih vjerskih ili društvenih praksi posebno važnih za pojedinca ili zajednicu. U kontekstu vjerskih običaja, pojmom obred određujem pojedinačne (često i najznačajnije) dijelove cjelokupne vjerske ceremonije, poput dijeljenja i primanja sakramenata ili prinosa žrtve. S druge strane, pojam rituala, iako može poslužiti kao sinonim obreda, istodobno obuhvaća šire područje vjerskog djelovanja te može uključivati niz radnji koje prethode ili zaokružuju središnji vjerski obred ili, pak, određivati običaje i pravila cjelokupne ceremonije. Također smatram da obred treba vezati uz vjerske bogoštovne prakse, dok ritual može obuhvaćati šire područje radnji uključenih u vjerske ceremonije, te se odnositi na različite sekularne načine ljudskog ponašanja i djelovanja. 
stijanizacije autohtonog američkog stanovništva. Takva struktura izvedbe, $\mathrm{u}$ kojoj su pretežito sudjelovali Indijanci, utjecala je na povezivanje njihovih igranih dramskih uloga sa stvarnim obrednim funkcijama, olakšavši među sudionicima preuzimanje novih vjerskih identiteta. Analizom dvaju običaja obrednog prevrednovanja dramske izvedbe prikazat ću kako su spomenute dramatizacije biblijskog sadržaja utjecale na doživljaj kazališnog predstavljanja kao stvarnog obrednog iskustva za indijanske obraćenike.

Primjeri koji će tvoriti temelj za analizu navedene evangelizacijske metode nastali su kao rezultat osobitog sinergijskog odnosa kazališnog i obrednog djelovanja u preoblikovanju vjerskog sustava autohtonih američkih zajednica. Već je sredinom prošlog stoljeća Duvignaud uputio na potrebu proučavanja kazališnog izraza u odnosu na njemu slične kulturne, vjerske i društvene prakse, uputivši na povezanost društvenog značenja kazališnog izraza i kazališnu vrijednost kolektivnih društvenih činova koje je opisao sintagmama "društvene predstave", "spontano kazalište", odnosno "svečanosti" (1970: 9). Umjetničko dramsko stvaralaštvo i društveno djelovanje ostvaruju se izvedbom i predstavljanjem tema važnih za zajednicu njihovim potvrđivanjem ili problematiziranjem te, stoga, tvore komplementarne tendencije iste snage i sadrže brojne istovjetne značajke. Obje prakse odlikuje: zadani izvedbeni kôd, preuzimanje uloga među sudionicima, individualizacija protagonista (dramskih junaka ili povijesnih heroja) koji preuzimaju odgovornost za čitavu zajednicu, odnos glumaca ili heroja prema gledateljima ili široj zajednici (javnosti), scensko omeđivanje i oblikovanje prostora u kojem se događaj odvija, vremensko ograničenje, dramska struktura radnje u obliku uvoda, kulminacije i raspleta te rezultat koji događaj ostvaruje u zajednici kao mogućnost stvarne ili simboličke preobrazbe (Duvignaud 1970: 9-33).

Istim je smjerom i novija kazališna povijest nastavila propitivati utjecaj teatra na preoblikovanje kulturnih, nacionalnih, vjerskih i ostalih identiteta budući da "kazalište tematizira i reflektira ekscentričnu poziciju čovjeka (...) te da se [u njemu] uvijek radi o aspektima i faktorima koji nekoj osobi omogućuje da kaže 'ja', [da stvara] svijest o njoj samoj, te u tom smislu i samosvijest" (Fischer-Lichte 2010: 11). ${ }^{2}$ Neke od izvedbenih sličnosti između kazališnog, ritualnog, obrednog i svakodnevnog ponašanja na koje upućuje Duvignaud problematizirali su Richard Schechner i Eugenio Barba. Schechner zastupa tezu o podudarnostima između kazališnog predstavljanja stvarnosti i svakodnevnog načina ponašanja, vidljivih u izvedbenim oblicima poput društvenog rituala, vjerskog obreda ili igre (Schechner 2006). S druge strane, Barba upućuje na njihove različitosti te određuje kazališni izraz kao rezultat čovjekove potrebe za umjetničkim oblikovanjem stvarnosti, različi-

${ }^{2}$ Svi prijevodi tekstova sa stranih jezika na hrvatski u ovom radu su autoričini, osim ako nije drukčije navedeno. 
tim od svakodnevnog djelovanja (Barba 1995, 2005). Iako suprotstavljeni u teorijama, oba autora uočavaju da uobičajeno ljudsko ponašanje postaje izvedbom (kazališnom, ritualnom ili obrednom) kad se ljudske radnje oblikuju i ponavljaju na poseban, stiliziran način, u skladu sa zadanom izvedbenom normom, kad sudionici preuzimaju zadane uloge i uspostavljaju nove međuodnose te kad se takvo djelovanje smješta u jedinstven scenski prostor i ambijent koji potiče izvedbeno ponašanje. Smatram da navedene podudarnosti mogu u određenim okolnostima, kao u primjeru evangelizacijskih kazališnih postupaka, dovesti do promjene izvedbenog značenja umjetničkih oblika, odnosno obrednog prevrednovanja dramskog prikaza kad se dovede u vezu s njemu sličnim izvedbenim ponašanjem, i tako utjecati na društvene promjene koje su izvan primarnog dosega kazališnog medija.

Schechner ujedno upućuje na osobit odnos i način uzajamnog latentnog međudjelovanja kazališne umjetnosti i društvenih zbivanja, pri čemu društvena potreba za promjenom iz javne sfere prelazi u kolektivnu podsvijest gdje se umjetnički "prerađuje" te ponovno "pušta" u javnu zonu. Taj proces ocrtava krivuljom (u obliku vodoravno položene znamenke broja osam) koja prikazuje kretanje i prijelaz javnog društvenog djelovanja ili izvedbe identiteta prema implicitnoj kazališnoj ideji koja postaje temeljem umjetničkom djelu. Ono pak dramskom izvedbom nanovo postaje vidljivim djelatnikom društvenih zbivanja te nakon prikazivanja počinje utjecati na promišljanje novih promjena u nevidljivoj zoni, a zatim se iste ideje ponovno ostvaruju na razini javnog djelovanja i time započinju novu putanju društveno-umjetničkog, odnosno ritualno-kazališnog međudjelovanja (2006: 68). Štoviše, Schechner uviđa i strukturalne sličnostiizmeđu kazališnog predstavljanja stvarnosti koje "jest izvedba" (engl. is performance) i svakodnevnih ili društvenih rituala "nalik izvedbi" (engl. as performance) (2006: 38) te model njihove realizacije opisuje trodijelnim procesom "pred-izvedbe" (engl. proto-performance), "izvedbe" (engl. performance) i "rezultata" (engl. aftermath) (2006: 225). ${ }^{3}$ Shema i značajke svake od faza uvelike podsjećaju na van Gennepov model ${ }^{4}$ "obreda prijelaza", koji se odvija "separacijom",

\footnotetext{
${ }^{3}$ Schechner predizvedbom označava početni stadij ili impuls u obliku dramskog, glazbenog ili kakvog drugog predloška, pravila izvođenja obreda ili neke radnje, postojanje situacije koja zahtijeva izvedbu, uvježbavanje izvedbe, propitivanje procesa nastanka, odabiranje mogućnosti izvedbe i objedinjavanje smislene cjeline. Pod izvedbom podrazumijeva prostorno i vremensko omeđivanje događaja, prijelazne faze iz uobičajenog djelovanja prema izvedbenom te njegovu izvedbu i prigodom koje se ostvaruje jedinstven odnos između izvođača i publike. Rezultat se opisuje kao trag izvedbe u vremenu nakon realizacije, odnosno komentar, pohranjivanje i sjećanje na isti događaj (2006: 225-249).

${ }^{4}$ Arnold van Geenep je uočio da u ljudskom životu velike promjene zahtijevaju prilagodbu pojedinca ili zajednice na novonastalu situaciju te se ona ostvaruje postupnim prijelazom od prijašnje uloge ili društvenog sustava prema novim strukturama uvjetovanim promjenama. Bilo da je riječ o mijenama prirodnog životnog ciklusa (rođenje, prijelaz iz djetinjstva u mladenaštvo, smrt) ili o preuzimanju obiteljskih i društvenih uloga (zaruke, vjenčanje), oblikovanje nove uloge ostvaruje se putem trodijelne sheme "obreda prijelaza", koji započinju "separacijom" ili "predliminalnim" obredima, razvijaju se "tranzicijom"
} 
"tranzicijom" ("liminalnom" fazom) i "integracijom" (1960: 10), iz čega je razvidno da Schechner uočava mogućnost primjene obredne strukture na različite umjetničke žanrove. Međutim, potonji ujedno upozorava na razliku u izvedbenom rezultatu, odnosno na činjenicu da teatar samo privremeno "transportira" pojedinca u trenutku umjetničke izvedbe, dok obred zadire u društvene strukture i vodi k završnoj "transformaciji" njezinih članova (2006: 63). Victor Turner također nasljeduje i razrađuje van Gennepove postavke u analizi društvenih sukoba uz pomoć dramske strukture "loma", "krize" i "obnove" (1989: 229-231). Opet je središnji, krizni, dio vezan uz van Gennepovo liminalno polje djelovanja koje sadrži "mogućnost kulturne inovacije, kao i stvaranje sredstava kojima se može djelovati na strukturalne promjene unutar razmjerno stabilnog sociokulturnog sustava" (Turner 1989: 178). Čak i kad ne dolazi do promjene, struktura društvene drame uvodi logiku u povijesni proces i pomaže "misliti" i prevladati krizno razdoblje kako bi se sustav osnažio za budućnost. René Girard opisuje obredno djelovanje kao simboličko razrješenje (nekadašnje) krizne situacije, čime se preventivno zaustavlja nasilno ponašanje koje bi ponovna stvarna kriza mogla uzrokovati. Stoga sjećanje na taj trenutak želi biti "prizivano, slavljeno, ponavljano i oživljavano" (Girard 1990: 134) kontinuiranim predstavljanjem i izvedbom koji omogućavaju privremenu subverziju sustava i obredno igranje nekadašnjeg nasilnog čina, a radi potvrđivanja zadanih struktura i suzbijanja svake promjene. Navedenim liminalnim iskustvima Turner, naposljetku, kontrapunktira "liminoidno" (1989: 62) društveno djelovanje svojstveno modernom dobu. Analizom jednostavnih društava upućuje na neprekidnu ritualizaciju ponašanja u kojem je igranje uloga nerazdvojno od života te rituali i obredi sadrže liminalne značajke koje dovode do poistovjećivanja izvođača s njihovim obrednim ulogama i trajne preobrazbe kolektiva. Tomu nasuprot uočava da moderno doba razdvaja sferu dokolice od sfere rada i time uvjetuje nastanak različitih žanrova kulturnih predstava poput umjetnosti, zabave, sporta, igre ili rekreacije, a kojima pripada i kazalište (1989: 62-114). Takvu privremenu preobrazbu, blisku Schechnerovu pojmu transportacije, određuje pojmom liminoidnog jer zadržava ritualnu struktu-

ili "liminalnim" obredima te završavaju "inkorporacijom" ili "posliminalnim" obredima. Obredima separacije autor označava radnje kojima pojedinac napušta uobičajeno okruženje kako bi odvajanjem od svoje dotadašnje uloge omogućio oblikovanje nove. Odvajanje može biti prostorno (poput odlaska iz doma ili odvajanja od obitelji), premda tek njegova mentalna i duhovna dimenzija dovodi do prekida s ranijim principom djelovanja. Proces se nastavlja obredima tranzicije u kojima pojedinac ili grupa preispituju dotadašnje uloge i mogućnosti preuzimanja novih oblika društvenog ponašanja. Njihovo izvođenje slijedi nakon obreda separacije i odvija se u okruženju koje ne pripada uobičajenom i svakodnevnom (može biti prostorno izdvojeno ili samo preoblikovano) kako bi se stvorio materijalno i mentalno "slobodan" prostor za prevrednovanje starih i formiranje novih društvenih uloga. Posljednji u nizu, obredi integracije, odgovaraju radnjama koje nakon preoblikovanja uloga uvode promijenjenog pojedinca ili grupu u početno društveno okruženje iz kojeg su krenuli. Funkcija posljednje vrste obreda sastoji se u uklapanju novih društvenih uloga u sustav (1960: 10-12). 
ru, ali nakon faze propitivanja, igranja novih uloga i trenutačnog zadovoljenja potrebe za eksperimentiranjem, ponovno vraća pojedinca ili zajednicu u prvobitno stanje i ne zadire u stvarne društvene strukture.

Uvidom u spoznaje na području novih teorija izvedbenih umjetnosti, smatram da se postupak obredizacije španjolskog crkvenog prikazanja u okviru misionarskih evangelizacijskih metoda može opisati na temelju analize istovjetnih strukturalnih značajki obreda i kazališta te procesa njihova društvenog, odnosno vjerskog međudjelovanja. Prihvatimo li Turnerovo shvaćanje društvenih mijena kao procesa u kojem "žanrovi poput obreda, ceremonije, karnevala, festivala, igre, spektakla, parade, sporta, mogu tvoriti, na različitim razinama i u različitim verbalnim i neverbalnim kodovima, niz isprepletenih metajezika" (1989: 213), uviđamo potrebu za tumačenjem šireg konteksta u kojem je sprega različitih izvedbenih oblika sadržanih u praksi kazališne evangelizacije i pokrštavanja utjecala na stvaranje liminalnog iskustva putem liminoidnog kazališnog medija. Iberski se dramsko-didaktični model, kojime su se sudionici privremeno transportirali tijekom predstavljanja duhovne teme, u specifičnim evangelizacijskim okolnostima preoblikovao u obredni model trajne transformacije u trenutku živog ostvarenja kršćanskog obreda. Primjere takve prakse prikazat ću analizom običaja dramatizacije i obredne realizacije, odnosno obredizacije dramskog prikaza Bogojavljenja i primanja sakramenta krštenja u sklopu evangelizacijske kazališne prakse u Meksiku u 16. stoljeću.

\section{DRAMATIZACIJA BOGOJAVLJENJA U EUHARISTIJSKOM OBREDU}

Kako prenosi De Ciudad Real u opisu svetkovine blagdana Sveta tri kralja u Jaliscu 1587. godine, običaj inscenacije klanjanja kraljeva pred malim Isusom ustalio se vrlo brzo među indijanskim pokrštenicima:

Među stanovništvom Tlaxomulca već se odavna ustalio običaj da svake godine na blagdan Bogojavljenja prikazuju što se dogodilo na taj dan onako kako kazuje i uči naša sveta Crkva. (De Ciudad Real 1873: 39)

Misionarska izvješća iz tog razdoblja također opisuju načine dramatizacije Bogojavljenja te navode primjere uvođenja dramskog prikaza u obred euharistije kao jednog od načina povezivanja kazališne izvedbe sa stvarnošću obrednog doživljaja. ${ }^{5}$ Najstarija očuvana kopija dramskog teksta na jeziku náhuatl, Klanjanje mudraca, datira iz 1760. godine. Međutim, jednostavnost prikaza i izlaganje teme po uzoru na didaktičan diskurs indijanskih huehu-

${ }^{5}$ Primjerice, jedan od prvih franjevaca uključenih u misije na prostoru današnjeg Meksika, Toribio de Benavente, spominje takav običaj u 13. poglavlju svog izvješća Historia de los indios de la Nueva España iz 1541. 
etlatollija ${ }^{6}$ upućuju da je pronađeni rukopis kopija teksta nastalog u ranom razdoblju evangelizacije u kojem su franjevački misionari nastojali približiti strukturu propovijedi autohtonim obrazovnim modelima. Autor dramskog teksta nije poznat, ali se također pretpostavlja da je djelo franjevačkog misionara jer odražava dobro poznavanje govorničkog stila i jezika náhuatl te predstavlja sinergiju kršćanskog i indijanskog načina prikazivanja, u skladu s franjevačkim načinom propovijedanja. Stoga možemo pretpostaviti da je taj ili sličan dramski tekst mogao poslužiti kao predložak brojnim izvedbama već u prvim godinama misionarskog rada. U ovom istraživanju služit ću se verzijom teksta u izdanju Fernanda Horcasitasa, koje sadrži uvodnu analizu, izvorni tekst na jeziku náhuatl te prijevod na španjolski jezik. Ujedno, u zapisima kroničara Antonia de Ciudad Reala nalazimo detaljan opis običaja izvedbe istog dramskog djela, što će nam dodatno pomoći u rekonstrukciji dramsko-obrednog događaja.

Izvedba Klanjanja mudraca ujedinjavala je više scenskih prostora: grad, crkveno dvorište i crkvu, te je tim redom postupno vodila sudionike iz područja svakodnevnog života prema sakralnom središtu događaja. De Ciudad Real navodi da je prikazanje započinjalo scenom dolaska kraljeva izdaleka, pri čemu su prostorno-vremenski odnosi premašivali uobičajeni okvir kazališne izvedbe:

S jednog od visokih brda koja su okruživala selo spustili su se kraljevi na konjima, vrlo polagano i dostojanstveno, što zbog svečanosti izvedbe, što zbog visine brda i neprohodnosti puta, tako da im je trebalo skoro dva sata da se spuste i pristignu u [crkveno] dvorište. (De Ciudad Real 1873: 39)

Kako vidimo iz opisa, nije samo mjesto svakodnevnog života dobilo funkciju dramskog prostora nego se i vrijeme trajanja dramske radnje u potpunosti preklapalo sa stvarnim vremenom i uvjetima putovanja u sceni spuštanja kraljeva s planine. Time je predstava već od samog početka bila bliža obrednoj nego dramskoj izvedbi jer je trajanje izvedbe potpuno odgovaralo stvarnom vremenu događaja, a prostor je obuhvaćao i "ne-kazališno" područje, znatno šire od uobičajene dramske scene.Vođeni zvijezdom, mudraci su se spustili u grad i stigli pred crkveno dvorište, u kojem je bio smješten Herodov dvor.

Kad su kraljevi pristigli pred dvorišni ulaz, zvijezda se skrila iza jednog od tornjeva te su Herodu poslali poruku da im dopusti ući, i nakon nekoliko molbi i odgovora sjašili su s konja i ušli u dvorište pred Heroda... (De Ciudad Real 1873: 41)

${ }^{6}$ Huehuetlatolli, indijanske moralne i vjerske upute namijenjene mladima, koje su se generacijski prenosile s roditelja na djecu ili su ih vladari upućivali podanicima. Osobitosti tog oblika usmene predaje pokazale su se idealnima u ispunjavanju pedagoške i obrazovne dimenzije evangelizacije, tvoreći ujedno poznat i pristupačan način izlaganja za lokalno stanovništvo. 
Dramska je radnja započela u gradskom području, ali je ulaskom triju kraljeva u palaču prešla u sakralni i izvedbeni prostor crkvenog dvorišta. Nakon objave radosne vijesti mudraci su se uputili prema Betlehemu, odnosno sceni jaslica smještenoj uz oltar. Didaskalije sačuvanog dramskog teksta potvrđuju kroničarev zapis te donose podatak o prostornim uvjetima izvedbe. Jaslice i scenu klanjanja mudraca smještaju uz oltar unutar crkvenog prostora, za razliku od svjedočenja De Ciudad Reala, prema kojem se jaslice nalaze uz crkveni ulaz. Prema dramskom tekstu prvi se dio predstave od objave radosne vijesti kraljevima do dolaska pred Betlehem izvodio u crkvenom dvorištu, a zatim se pojavom zvijezde vodilje na vratima crkve premještao u sakralni prostor, od crkvenog ulaza do oltara, uz koji su bile postavljene jaslice (Horcasitas [1974] 2004: 321-322). Iako su razlike između dramskog teksta i kroničareva zapisa neznatne, didaskalije govore u prilog teoriji o povezivanju scenskog prostora i tijeka izvedbe drame s euharistijskom slavljem, dok opis izvedbe ne spominje takvo povezivanje i smješta čitavo prikazanje u prostor crkvenog dvorišta (De Ciudad Real 1873: 41-43). Uzevši u obzir osobitosti sakralne arhitekture Nove Španjolske, moguće je pretpostaviti da tekstovi donose tek različite opise istog scenskog rješenja, odnosno da su u oba primjera jaslice bile smještene u otvorenoj kapeli, ${ }^{7}$ dovoljno prostranoj da primi veliki broj vjernika. Mišljenje zasnivam na činjenici da smještaj i opis scene jaslica kod De Ciudad Reala odgovara položaju otvorene kapele u crkvenom dvorištu te da je u dramskom tekstu logika izvedbe nalagala vidljivost čitavog tijeka dramske radnje svim vjernicima u istodobnom odvijanju predstave i mise.

Takav tijek izvedbe omogućio je poklapanje dramske radnje s obredom euharistije, a njihovo prožimanje započelo je scenom prilaska mudraca jaslicama uz crkveni oltar. U crkvu prvo ulazi glasonoša:

Melkior: Idi, slugo naš, uđi i razgledaj. Da vidimo kakvo čudo nam je pripremio naš Bog i Gospodin.

Glasnik: Dobro, gospodo. Dopustite da uđem i pogledam.

Glasnik ulazi u crkvu. Razgledava. Ponovno izlazi i govori.

(Horcasitas [1974] 2004: 321)

U opisu izvedbe De Ciudad Reala također postoji podatak da je s kraljevima išao "pješice jedan Indijanac kao vodič ispred [mudraca], a iza njih je išao drugi [...] i nosio darove za maloga Isusa" (De Ciudad Real 1873: 40). Mi-

\footnotetext{
${ }^{7} \mathrm{~S}$ obzirom na brojnost indijanskog stanovništva i ideju o njihovu što bržem pokrštavanju i vjerskoj edukaciji, propovijedi su se često održavale na otvorenom, u crkvenim dvorištima i atrijima koji su mogli okupiti veći broj vjernika. Radi toga su se počele podizati otvorene kapele (capillas abiertas, španj., pl.), jednim dijelom otvorene prema crkvenom dvorištu, a bočno zatvorene njegovim zidovima, nalik prezbiteriju na otvorenom.
} 
šljenja sam da je uloga glasonoše prema dramskom tekstu ujedno trebala pridonijeti stvarnosti prikaza, pri čemu su se kraljevi prikazivali kao stvarne osobe u situaciji oklijevanja i pripreme za susret s božjim djetetom. Osim toga, ulaz glasnika u otvorenu kapelu zasigurno je imao funkciju prizivanja pažnje vjernika koji su se nalazili bliže oltaru i najave svečanog ulaska kraljeva. Didaskalije o njihovu prilasku jaslicama na sljedeći način opisuju razvoj događaja:

Ovdje mudraci silaze s konja. Ulaze u crkvu. Koračaju polako i dostojanstveno. Kleknu pred oltar gdje se govori misa. Zatim, tijekom Evanđelja, nakon Vjerovanja, smjerno pozdravljaju ljubljeno i blaženo Dijete Božje te počinju moliti. (Horcasitas [1974] 2004: 322)

Didaskalije izravno upućuju na postupak obrednog prevrednovanja dramske izvedbe, odnosno uvođenja kazališne predstave u strukturu misnog slavlja. Navode dio u kojem se dramska radnja zaustavila te su likovi mudraca počeli sudjelovati u obredu homilije i molitve kako bi se po završetku ponovno uključili kao dramski izvođači i nastavili prikaz klanjanja pred malim Isusom. Stoga možemo reći da je njihovim ulaskom u crkvu čitav sakralni prostor postao liminalnim područjem za istodobno odvijanje dramatizacije Bogojavljenja i realizacije obreda euharistije kao poveznice između kazališne i obredne stvarnosti događaja.

Scena klanjanja završila je replikom lika Anđela koji savjetuje kraljevima neka na povratku krenu suprotnim smjerom kako Herod ne bi otkrio Isusovo boravište. Potom završava misa, a slijedi posljednja dramska scena:

Kad završi misa, [Anđeo] pozove Josipa. Savjetuje ga. Kaže:

Josipe! Bježi s ljubljenim Božjim sinom. Hulja Herod već ti je za petama i traži te. Odvedi ga u Egipat. Sakrij ga pod list velike palme. Čuvaj ga tamo kako ga ne bi osudili na smrt jer će Herod ubiti svu djecu. Žurno! Trči brzo, Josipe dragi! (Horcasitas [1974] 2004: 325)

Očevidno je da je između Anđelova savjeta kraljevima i njihova odlaska te govora Josipu došlo do stanke u izvedbi predstave sve do završetka mise, a zatim se ponovno javlja glas dramskog lika i time zajedno završavaju obje izvedbe, dramska i obredna. U De Ciudad Reala nalazimo istovjetan opis izvedbe i podatak o sastavu i broju vjernika koji su prisustvovali događaju.

Zatim se pojavio anđeo [...], i rekao kraljevima da se vrate u svoju zemlju drugim putem, i tako su izašli iz dvorišta te je slavlje završeno. Događaju je prisustvovalo deset ili dvanaest redovnika i puno Španjolaca te više od pet tisuća Indijanaca iz tog kraja i obližnjih mjesta jer svi koji žive na tom području dolaze sudjelovati u ovom slavlju. (De Ciudad Real 1873: 41) 
Zaključujem da kazališni prikaz nije samo u jednom trenutku prekinuo uobičajeni tijek mise kao dramatizirano pojašnjenje čitanja Svetog pisma i propovijedi, već se od prilaska likova kraljeva oltaru paralelno izmjenjivao s odvijanjem obreda i tvorio s njime jednu izvedbenu cjelinu. Kazališna radnja dijelila je prostor i vrijeme s vjerskim obrednim djelovanjem te se odvijala i završila paralelno s njime u stvarnom vremenu događaja. Takvo prožimanje dramske i obredne stvarnosti stvorilo je dojam autentičnosti kazališnog prizora i obrednog djelovanja dramskih uloga jer je publika mogla scenski događaj izravno povezati s iskustvom prvog susreta s franjevcima i njihovim propovijedanjem.

Takvu tumačenju u prilog govore i povijesne činjenice iz razdoblja u kojem je ovaj običaj zaživio među Indijancima. Riječ je o podudarnostima između biblijskog Bogojavljenja i njihova osobnog iskustva susreta s misionarima koji su naviještali Evanđelje u trenutku za koji se vjerovalo da je svršetak posljednjeg životnog razdoblja indijanskih naroda. Naime, vjerska su predviđanja indijanskih zajednica na srednjoameričkom prostoru desetljeće prije dolaska Europljana u Novi svijet naviještala svršetak svoga petog životnog ciklusa dolaskom stranaca s mora. U skladu s vjerovanjem, njihov dolazak najavile su neobične pojave u prirodi poput vatrenih tragova na nebu, neugasivih požara i sličnih fenomena koje su Indijanci počeli primjećivati nekoliko godina prije dolaska kolonizatora. ${ }^{8}$ Zbog nekarakterističnog odstupanja od prirodnih zakona, takve su se pojave tumačile kao znakovi koji upozoravaju na dolazak velikih promjena. Predviđanja su smještala svršetak životnog ciklusa upravo u razdoblje otkrića Novog svijeta te je dolazak Europljana potvrdio završetak pete, ujedno i posljednje faze cikličkog ponavljanja povijesti, koji je značio propast dotadašnje civilizacije. Time su indijanska vjerovanja otvorila put budućim vjerskim i kulturološkim promjenama izmijenivši odnos prema prošlosti, budućnosti i pitanju održivosti njihova dotadašnjeg vjerskog i kulturnog sustava.

S obzirom na podudarnosti između indijanske predaje i nauka o Bogojavljenju, dramatizacija navještenja i Isusuova rođenja mogla je imati osobito značenje za novohispanske vjernike. Primjerice, pojava zvijezde vodilje u kršćanskoj objavi dovodila se u vezu s pojavom vatrenih tragova na nebu i požara koji su tumačeni kao znak dolaska novih duhovnih vođa. Ujedno,

\footnotetext{
${ }^{8}$ Sažeti prikaz astečke usmene predaje preuzimam iz djela Miguela León-Portilla, Visión de los vencidos -Relaciones indígenas de la Conquista. Autor donosi prijevod tekstova iz Códice Florentino, rukopisa na jeziku náhuatl, koji sadrži zapise o razdoblju indijanske povijesti neposredno prije dolaska Europljana te svjedočanstva o prvim godinama osvajanja i kolonizacije, sve do zauzimanja grada Tenochtitlána. Svjedočanstva je zabilježio i objedinio misionar Bernardino de Sahagún u 16. stoljeću prema navodima svojih indijanskih izvjestitelja. Sahagúnove bilješke León-Portilla nadopunjava tekstovima iz Historia de Tlaxcala, Diega Muñoza Camarga, jednog od prvih povjesničara kreolskog porijekla koji je zabilježio iskustvo ranih godina kolonizacije predhispanskog grada-države Tlaxcale.
} 
katehetski tekst Razgovori i kršćanski nauk jednog od prvih franjevačkih misionara, Bernardina de Sahagúna, upućuju na podudarnost između scene anđeoske objave pastirima, replika mudraca pred Isusom i misionarskog načina izlaganja kršćanske doktrine. Iz Razgovora preuzimam ulomak uvodnog obraćanja misionara indijanskim glasnicima, a zatim citat iz Horcasitasove rekonstrukcije dramskog predloška za izvedbu Navještenja pastirima iz Sinaloe (Coloquio de los pastores de Sinaloa) kojima su mogle biti dopunjene božićne inscenacije:

Prije svega vas molimo da se ne uznemirite niti prestrašite [...] nosimo vam poruku Gospodina koji ima duhovnu moć nad svim živima, a zove se Sveti Otac. (Sahagún 1986: 79)

Ne bojte se i ne strašite. Javljam vam prekrasnu vijest da vam se rodio spasitelj svijeta. On je sin Boga, Isus Krist. (Horcasitas [1974] 2004: 284-285)

Primjeri pokazuju da je misionarsko obraćanje Indijancima formalno i sadržajno slijedilo način izlaganja u dramskom prikazanju. Potom je scena klanjanja i prinosa darova božićnim jaslicama u tekstu Klanjanja mudraca praćena riječima štovanja sličnih misionarskoj propovijedi. U dramskom tekstu kralj Melkior se klanja pred Isusom i slavi ga riječima:

Ti si pravi čovjek i Bog, ljubljeni Gospodine božji. Vjerujem u tebe svim srcem. Vjerujem da si stvorio nebo i zemlju, vidljivo i nevidljivo. Uistinu si doveo svoje kraljevstvo kako bi vladao i vodio svijet. I sva tvoja stvorenja su te toliko dugo čekala. (Horcasitas [1974] 2004: 323)

Sahagúnovi Razgovori na sličan način predstavljaju Stvoritelja:

Zove se Isus Krist, pravi Bog i pravi čovjek, stvoritelj života i svijeta, otkupitelj i spasitelj svijeta; bez početka, vječan; on je stvorio nebo i zemlju i pakao; stvorio je sve ljude na zemlji [... ] a ovdje na zemlji također ima svoje kraljevstvo, koje postoji otkad je svijeta i u koje i vas sada želi uključiti te se trebate osjećati počašćenima. (Sahagún 1986: 83-84)

Podudarnost dramskih situacija i replika sa stvarnom situacijom prvog kontakta kršćana i Indijanaca te propovjednim diskursom franjevaca zasigurno je utjecala na povezivanje dramske izvedbe sa stvarnim iskustvom misionarske objave Kristove vladavine. Stoga ne čudi podatak da se upravo obilježavanje blagdana Sveta tri kralja i običaj igranja scene klanjanja u blagdanskom razdoblju vrlo brzo ustalio među lokalnim stanovništvom. 0 tome piše Toribio de Benavente na sljedeći način: 
Blagdan Sveta tri kralja osobito slave jer ga doživljavaju kao njima blisko slavlje: i često na taj dan izvode prikazanje o klanjanju mudraca pred malim Isusom i donose zvijezdu izdaleka jer za izradu i bacanje konopa nije potrebno tražiti znalce pošto svi ovi Indijanci, djeca i odrasli, znaju uvijati konop. A u crkvi postave Djevicu Mariju i predragog Isusa u jasle, pred koje taj dan polažu svijeće, tamjan, golubove, prepelice i druge ptice koje pripreme za taj dan, i tako se do sada među njima ustalilo štovanje ovoga blagdana. (Benavente [1541] 2000: 70)

Prema riječima misionara možemo pretpostaviti da je prikazanje o Sveta tri kralja uistinu bilo osobito važno za lokalno stanovništvo pa jedan od razloga možemo tražiti $\mathrm{u}$ analognoj povezanosti novozavjetne teme s povijesnim trenutkom susreta Indijanaca i franjevaca. Igranje tog događaja inscenacijom biblijske priče i istodobno sudjelovanje u kršćanskom obredu moglo je potaknuti kolektivno prisjećanje na kriznu ili liminalnu situaciju i omogućiti njezino prevladavanje obredno-kazališnim igranjem povijesnog događaja. Pretpostavljamo da očuvani dramski tekst nije bio namijenjen samo jednom izvođenju, nego se koristio kao tekstualni predložak za izvedbu mnogih prikazanja. Tematska i izvedbena povezanost drame Klanjanje mudraca s obrednim radnjama utjecala je na stvaranje liminalne zone u kojoj se stvarnost kazališne igre preklapala s obrednom stvarnošću, a dramske uloge dobivale vrijednost obrednih funkcija. Prema istom načelu, gledatelji nisu prisustvovali samo u ulozi publike već su bili uključeni kao "svjedoci” događaja u stvaranje obrednog zajedništva i oživljavanje sjećanja na nekadašnju transformaciju inscenacijom Isusova rođenja.

\section{OBRED KRŠTENJA U DRAMATIZACIJI BITAKA MAURA I KRŠĆANA}

Sakrament krštenja je predstavljao obrednu inicijaciju autohtonog indijanskog stanovništva u zajednicu kršćana. Budući da su misionari bili vođeni idejom o žurnoj kristijanizaciji brojnog stanovništva Srednje Amerike, često su organizirali masovne podjele sakramenta krštenja. ${ }^{9}$ Opis takvog obreda u okviru kazališne izvedbe nalazimo u izvješću o svetkovini Tijelova u Tlaxcali 1538., kad je prikazano Osvajanje Jeruzalema kao dramatizacija "bitke Maura i kršćana" (španj. danza de moros y cristianos). Riječ je o jedinstvenoj vrsti plesne inscenacije iberske tradicije u kojoj se plošnim prikazom povijesnih bitaka muslimana i kršćana te prožimanjem stvarnih događaja i kršćanske predaje veličao vjerski i politički značaj imperija u obrani Europe od musli-

\footnotetext{
${ }^{9}$ Takva se praksa često spominje u misionarskim izvješćima prvih franjevaca u Novome svijetu. Primjerice, Juan de Torquemada ju opisuje u 11. poglavlju 16. dijela knjige Monarquía indiana, a slično prenosi i Toribio de Benavente u 3. poglavlju II. dijela Historia de los indios de la Nueva España.
} 
manske prijetnje. ${ }^{10}$ Iako ti plesovi nisu tematizirali Evanđelje kao ostale misionarske drame, u Novome su svijetu imali važnu ulogu kao jedan od načina dramske evangelizacije. Budući da su predstave završavale porazom i preobraćanjem protivničke maurske vojske, misionari su se često služili takvim oblikom dramsko-obrednih izvedbi u prikazu pobjede kršćana i istodobnom pokrštavanju dramskih Maura, odnosno indijanskog stanovništva. Iako je opis Osvajanja Jeruzalema jedini očuvani zapis o načinu inscenacije takvih bitaka u Novome svijetu, možemo pretpostaviti da je u sličnim okolnostima izvedeno Osvajanje Rodosa u Meksiku 1539. i Bitka kod Lepanta 1572. godine te barem jedna predstava temeljena na očuvanom dramskom tekstu Uništenja Jeruzalema. ${ }^{11}$ Navedeni podatci govore u prilog teoriji da je pridavanje obrednog značenja dramskom prikazu u više prilika odigralo važnu ulogu u stvarnom preobraćenju mnogobrojnog autohtonog stanovništva današnjeg Meksika.

Scenografija za izvedbu Osvajanja Jeruzalema postavljena je u samom središtu grada, a u oblikovanju dramske kulise koristila se postojeća gradska arhitektura na koju je nadograđena privremena pozornica te je već takav postupak utjecao na stvaranje liminalne zone dramsko-obrednog prikaza.

U Tlaxcali, gradu koji su nanovo počeli podizati, u središtu prostora sravnjenog sa zemljom postavili su velik i vrlo lijep trg, na kojem su načinili Jeruzalem ponad zgrada u kojima će biti vijećnica, na mjestu gdje su već postavljeni temelji budućih zgrada; gdje je već posuta zemlja i započeta gradnja; i načinili su pet tornjeva; jedan veliki u sredini, i četiri manja na uglovima... (Benavente [1541] 2000: 87-88)

Primjer slikovito prikazuje vještinu uklapanja scenografije u poznato gradsko okruženje, odnosno uvođenje kazališnih elemenata vezanih uz vjersko slavlje u prostor svakodnevnih i sekularnih aktivnosti. Podizanje takve scene na sravnjenoj površni grada Tlaxcale i temeljima budućih europskih institucija na meksičkom tlu moglo se u danim povijesnim okolnostima tumačiti kao još jedan vid zauzimanja političkog, kulturnog i vjerskog središta lokalnih zajednica. Budući da je tematska okosnica Osvajanja Jeruzalema bila sadržana u kršćanskoj opsadi i zauzimanju grada, preobrazba gradske scene

\footnotetext{
${ }^{10}$ Prve dramatizacije danzas de moros y cristianos iz 12. stoljeća uzimale su za tematsku okosnicu samo trenutak borbe, najčešće prikazan u scenama zauzimanja dvorca ili pomorske bitke. Od 15. stoljeća radnja se smješta u širi povijesni kontekst, poput Zauzimanja Granade (La toma de Granada), izvedene 1492. godine, neposredno nakon odigravanja slavnog događaja.

11 Izvedbu Osvajanja Rodosa spominje dominikanac Bartolomé de las Casas (1502-1566., 1992: 601-602) te španjolski osvajač u pohodima na srednjoameričkom prostoru, Bernal Díaz de Castillo ([1632] 1968: 566-572). U podatcima o izvedbi Bitke kod Lepanta uz kratak opis nalazimo i slikovni trag u piktografskom zapisu povijesti naroda Mexica, Códice Aubín iz 1576. godine ([1576] 1963: 113). Prijevod Uništenja Jeruzalema na španjolskom jeziku također je objavio Fernando de Horcasitas (1974.-2004.).
} 
Tlaxcale i dramski prikaz koji se na njoj trebao odviti označili su stvarno kršćansko osvajanje tog područja.

Prema izvješću Toribia de Benaventea, nakon dolaska procesije na trg, $u$ redovima kršćanske vojske na sceni su se pojavili brojni narodi Španjolskog Carstva:

Zatim je počela ulaziti španjolska vojska kako bi opkolila Jeruzalem te su prošli trgom ispred Presvetog Sakramenta i smjestili se nadesno. Trebalo im je dugo jer je bilo mnoštvo ljudi podijeljeno u tri eskadrona. Na čelu su išli noseći zastavu kraljevske vojske podanici Kastilje i Leóna, vojska generala Antonia Pimentela grofa od Benaventea, sa zastavama svoje vojske. Iza njih su išli vojnici Toleda, Aragonije, Galicije, Granade, Baskije i Navarre. Na začelju je išla vojska Njemačke, Rima i Italije. (Benavente [1541] 2000: 88)

Uloga predvodnika kršćanske vojske u borbi protiv muslimanske pripala je Španjolskom Carstvu pod vodstvom Antonija Pimentela, istaknutog borca vojske Karla V. u osvajanju Tunisa 1535. godine. Anakrono povezivanje srednjovjekovnih bitaka za grad Jeruzalem s tadašnjim prilikama i stvarnim povijesnim osobama bio je uobičajeni postupak osuvremenjivanja povijesnih tema. Njime se upućivalo na aktualnu situaciju turske prijetnje zemljama zapadnog kršćanstva te se inscenacijama kršćanskog otpora, u kojima je Španjolsko Carstvo imalo dominantnu ulogu, pridavala svevremenska vrijednost. Ujedno, povezivanje dramatizacije poznatog događaja s tadašnjim povijesnim okolnostima omogućilo je preklapanje značenja kazališnog prikaza i dramskih uloga sa stvarnim iskustvom sudionika događaja. Uvjetovana potrebama evangelizacije, uobičajena shema sukoba dviju zaraćenih strana u izvedbi Osvajanja Jeruzalema uključivala je i treći tabor - američki. Time su narodi koloniziranih područja Srednje i Južne Amerike uvedeni u izvedbu u ulozi kršćanskih pomagača.

Na čelu su išli vojnici Tlaxcale i Meksika; bili su naočiti i privlačili su pažnju; nosili su barjak kraljevske i generalove vojske, Antonija de Mendoze, potkralja Nove Španjolske. Postrojbu vojske činili su narodi Huaxteca, Zempoalteca, Mixteca, Colhuaque i generali Perua i otoka Santo Dominga i Kube. Na začelju su išli vojnici naroda Tarasca i Cuaulitemalteca. (Benavente [1541] 2000: 88)

Preoblikovanje tradicionalnog modela izvedbe očigledno je bilo osmišljeno radi ideološkog i vjerskog povezivanja autohtonog stanovništva s ulogom kršćana te isticanja njihove važnosti u borbi protiv Maura. Tadašnji potkralj Antonio de Mendoza igrao je generala američke vojske, iz čega je vidljivo da se u odabiru sudionika i dodjeljivanju uloga poštivala stvarna društvena hijerarhija te se značenje dramskog lika poklapalo sa stvarnim društvenim položajem izvođača. Prema istom je načelu maursku stranu u ulozi sultana 
predvodio konkvistador Hernán Cortés, upravo u doba stvarnog slabljenja njegove političke i vojne moći, uzrokovanog sukobom s tadašnjim novim političkim elitama na čelu s potkraljem Mendozom.

Prema tradicionalnom modelu prikaza, nakon izlaska kršćanske i maurske vojske te dolaska Presvetog sakramenta u pratnji pape, kardinala i biskupa na scenu, odigravalo se nekoliko bitaka. U Osvajanju Jeruzalema prvo se sukobila maurska vojska sa španjolskim snagama, koje su nastojale zauzeti Jeruzalem; zatim je u pomoć kršćanima pristigla američka vojska i započela novu bitku s muslimanima. Potom su se "pravovjernicima" priključile i savezničke snage Francuske i Ugarske. U stankama između bitaka prenosila se korespondencija između predvodnika kršćanske vojske i španjolskoga kralja te kralja i pape koji je bodrio kršćanske snage. Izvedba je završila uplitanjem anđela i svetaca koji su pomogli kršćanima u završnom porazu Maura (Benavente [1541] 2000: 88).

Uključivanjem svetaca i anđela uz koje su kršćani uspjeli izvojevati pobjedu željelo se svjetovnoj bitci dati jedinstveno duhovno značenje i prikazati pobjedu kršćanstva kao znak božje volje, čime bi se uputilo na neminovnost preobraćenja svih nekršćana po uzoru na maurske likove u dramskom prikazu. U kontekstu misionarske kateheze o značenju anđela u životu vjernika, njihova je uloga u preobraćenju dovedena u neposrednu vezu s borbom protiv starih indijanskih vjerovanja i kultova. Njih su, prema Sahagúnovim Razgovorima, proširili Lucifer i pobunjeni anđeli kako bi prevarili Indijance i naveli ih da štuju "kao boga sunce i mjesec i zvijezde, kao i kipove od kamena i drveta, te ptice i zmije i ostala bića" (Sahagún 1986: 93). U prikazu Osvajanja Jeruzalema u pomoć kršćanima prvo su stigli sveci; sveti Jakov, zaštitnik Španjolske i sveti Hipolit, zaštitnik Nove Španjolske, uz čiju pomoć su "Španjolci s Tlaxcaltecima osvojili Meksiko" (Benavente [1541] 2000: 94). Pojavljivanje svetog Hipolita povezivalo je prikaz bitke sa stvarnim povijesnim događajem osvajanja Meksika u kojem je svetac odigrao ulogu zaštitnika naroda Tlaxcalteca, odnosno grada u kojem je prikazano Osvajanje Jeruzalema. Potom se na sceni pojavio arkanđeo Mihovil i obratio se maurskoj vojsci riječima: "upoznajte Njegovo Veličanstvo, Stvoritelja svega svijeta, vjerujte u njegovog ljubljenog Sina, Isusa Krista, i stišajte njegovu srdžbu suzama i iskrenom skrušenošću" (Benavente [1541] 2000: 95). Nakon njegove replike sultan se predao na milost bogu i španjolskom kralju:

Velika je dobrota i milosrđe Božje jer je želio prosvijetliti nas u strašnoj sljepoći grijeha: došlo je vrijeme da spoznamo svoju pogrešku; do sada smo mislili da se borimo s ljudima, no sada uviđamo da se borimo s Bogom i njegovim svecima i anđelima: tko im se može oduprijeti? (Benavente [1541] 2000: 95)

Najznačajniji se trenutak odigrao u završnom dijelu ceremonijalnim uvođenjem obreda krštenja muslimanske vojske u dramatizaciju bitke: 
Kad je pročitao pismo [predaje], Kralj je krenuo prema već otvorenim gradskim vratima gdje ga je primio Sultan i njegova brojna pratnja; pred Kraljem se spustio na koljena i pokorio mu se, dugo mu ljubeći ruku; tada ga je Kralj podigao i uzeo za ruku te ga je doveo pred Presveti sakrament, uz koji je stajao Papa, i dok su svi zahvaljivali Bogu, Papa ga je primio s ljubavlju. S njim je išlo mnoštvo odraslih Turaka ili Indijanaca koje je trebalo pokrstiti, i tamo su javno zatražili krštenje od Pape, a zatim je Njegova Svetost poslala svećenika neka ih krsti te su odmah bili kršteni. Kada su završili, podignut je Presveti sakrament i procesija je krenula dalje. (Benavente [1541] 2000: 95-96)

Iz citiranog ulomka vidimo da je na kraju kazališne predstave uistinu izveden kršćanski obred u kojem je kršteno "mnoštvo odraslih Turaka ili Indijanaca", odnosno Indijanaca u ulozi Turaka. U tom je trenutku dramska uloga pape i ostalih svećenika s početka dramskog prikaza postala stvarnom obrednom funkcijom tijekom završnog obreda krštenja. Uključivanje svećenstva u izvedbu drame i masovnog krštenja nedvojbeno je u svijesti publike povezalo odigrane scene sa stvarnim iskustvom prostornog i duhovnog osvajanja Novoga svijeta i franjevačkog pokrštavanja Indijanaca. Dramski prikaz dao je tumačenje minulih povijesnih događaja i smisao netom proživljenom iskustvu preobraćenja među lokalnim stanovništvom. Postavlja se pitanje u kojem trenutku su se dramske uloge Turaka preobrazile u protagoniste obreda krštenja. Smatram da je dramski prikaz otvorio liminalno područje igranja novih vjerskih identiteta kao uvoda u obred te je njegova uklopljenost u stvarnost vjerskog slavlja omogućila postupno identificiranje izvođača $s$ dramsko-obrednom ulogom, sve do potpunog preuzimanja obredne funkcije krštenika u završnom primanju sakramenta.

U izvedbu je bilo uključeno više stotina izvođača, prema Horcasitasovoj analizi ukupan broj mogao je doseći čak 1500 osoba, od kojih je gotovo trećina igrala ulogu pokrštene muslimanske vojske (Horcasitas [1974] 2004: 621). Možemo pretpostaviti da su dramske uloge američke vojske preuzeli već pokršteni Indijanci, dok je još nepokrštenima pripala uloga Turaka koji su primili taj sakrament u obrednom završetku dramske izvedbe. Broj sudionika događaja, razrađenost kazališne kulise uklopljene u gradski prostor i ceremonijalnost izvedbe odredili su bitke kao jedan od najsvečanijih i najdojmljivijih oblika misionarske kazališne prakse. Jedinstven učinak takve obredno-kazališne vrste sadržan je u njezinu dvojakom djelovanju na preoblikovanje indijanskog vjerskog i političkog sustava. Sudjelovanje obraćenika kao pomagača kršćana u povijesnim okolnostima stvarne turske prijetnje odredilo ih je istodobno kao nove kršćane i kao vjerne podanike Španjolskog Carstva u borbi protiv muslimana. Budući da je struktura indijanske društvene uprave i vlasti počivala upravo na sjedinjenju vjerske i ratničke dimenzije u liku vladara i vrhovnih svećenika, vjersko preobraćenje Indijanaca pokrštenih tijekom izvedbe bitke postalo je znakom stvarnog poraza i prihvaćanja novog vjerskog i političkog ustroja Nove Španjolske. 


\section{ZAKLJUČNI KOMENTAR}

U okviru povijesnog razvoja hispanskih dramskih i izvedbenih vrsta, misionarski kazališni rad u Novome svijetu izniman je primjer obredne primjene dramskog žanra u procesu pokrštavanja. Iako su misionarska dramska djela začetno osmišljena prema modelu španjolskog crkvenog prikazanja, razlikovale su ih okolnosti izvedbe i namjena, što je izdvajalo takav način evangelizacije kao jedinstven primjer obredne prenamjene tradicionalne dramske vrste. Kontekst izvedbe misionarskih djela bio je djelomice temeljen na iberskim običajima slavlja Presvetog sakramenta, pri čemu je zadržao tradicionalne sastavnice događaja poput sakralizacije gradskog prostora, procesija, izvedbi crkvenih prikazanja i euharistijskog obreda. Razliku u odnosu na ibersku tradiciju uočavam u stapanju obrednih i kazališnih značajki događaja, odnosno u procesu obredne prenamjene dramskih oblika koja je omogućila stvaranje liminalnog područja potrebnog za preuzimanje novih ili potvrđivanje starih vjerskih identiteta.

U primjeru izvedbe dramskih predstava kakve sam opisala na primjeru Osvajanja Jeruzalema i Klanjanja mudraca, misionarska izvješća potvrđuju da se nije radilo samo o prikazivanju vjerskih običaja koje je Indijancima olakšavalo upoznavanje s kršćanskom vjerskom praksom. Razvidno je da obredno primanje sakramenata nisu misionari predstavljali indijanskoj publici, već su dramu i obred izvodili upravo Indijanci koji su sudjelovali u istovremenom predstavljanju događaja i njegovom živom ostvarenju u obredu. Kao što sam istaknula na početku, postupak uvođenja obreda u predstavu mogao se odviti prirodno jer sam obred sadrži mnoge kazališne značajke, poput scenskog preoblikovanja prostora, kostimiranja izvođača, preuzimanja novih uloga, strukturiranja biblijskih i povijesnih događaja logikom dramske priče te izvedbe pred publikom. Međutim, ustvrđujem da je istinsko proživljavanje dramskog događaja omogućila vezanost obreda uz stvarne, ne-kazališne okolnosti, vidljive u podudaranju trajanja izvedbe obreda sa stvarnim vremenom, njegovom smještanju u sakralno okruženje koje nema kazališnu namjenu, povezivanju dramsko-obredne izvedbe s povijesnim događajima i već proživljenim iskustvima vjernika te sudjelovanju članova zajednice koji su se trebali preobratiti dramatiziranim obrednim činom. U tom su smislu kazališni postupci iskorišteni u procesu napuštanja svakodnevnog životnog okruženja prema dramatiziranoj stvarnosti obreda, što je sudionicima olakšalo preuzimanje novih vjerskih uloga privremenim dramskim identitetima. Kontekst izvedbe vjerske svetkovine i povezivanje dramske radnje s kršćanskim obredima utjecali su na stvaranje liminalnog područja unutar liminoidnog žanra, odnosno otvaranje faze koja je omogućavala propitivanje i igranje društvenih i vjerskih uloga koje će u konačnici voditi prema trajnoj transformaciji sudionika ili pak ritualnom potvrđivanju novog vjerskog 
identiteta u zajedništvu ponovnog proživljavanja nekadašnjeg kriznog trenutka i njegova prevladavanja u obrednom slavlju. Zaključujem da je upravo uključivanje obrednih radnji poput krštenja i pričesti u takvo "nestabilno" područje dramske izvedbe utjecalo na doživljaj cijelog dramskog prikaza kao stvarnog duhovnog iskustva. Tako je izvedba koja je začetno osmišljena kao dramska postupno dobivala značenje istinskog djelovanja vjernika i utjecala na završno preuzimanje obrednih funkcija analognih njihovim dramskim ulogama.

\section{NAVEDENA LITERATURA I IZVORI}

Badurina, Anđelko, ur. 1979. Leksikon ikonografije, liturgike i simbolike zapadnog kršćanstva. Zagreb: Sveučilišna naklada Liber, Kršćanska sadašnjost, Institut za povijest umjetnosti.

Barba, Eugenio. 1995. The Paper Canoe. A Guide to Theatre Anthropology. London, New York: Routledge.

Barba, Eugenio i Nicola Savarese. 2005. The Secret Art of the Performer. A Dictionary of Theatre Anthropology. London, New York: Routledge.

Benavente, Toribio de. [1541] 2000. "Historia de los indios de la Nueva España". U Colección de documentos para la historia de México. Joaquín García Icazbalceta, ur. Alicante: Biblioteca Virtual Miguel de Cervantes. Dostupno na: http://bib.cervantesvirtual.com/servlet/ SirveObras/93348473656335907949368/p0000004.htm\#I_54_(pristup 13. 12. 2013.).

Castillo, Bernal Díaz de. [1632] 1968. Historia verdadera de la conquista de la Nueva España. Madrid: Espasa-Calpe.

Ciudad Real, Antonio de. 1873. Relación breve y verdadera de algunas cosas de las muchas quesucedieron al padre Fray Alonso Ponceen las povincias de la Nueva España, siendo comisario general de aquellas partes. Madrid: Imprenta de la Viuda de Calero.

Diccionario de la lengua española de la Real Academia Española. Dostupno na: http://lema.rae. es/drae/?val=sintesis (pristup 11. 9. 2014.).

Duvignaud, Jean. 1978. Sociologija pozorišta. Beograd: BIGZ.

Códice Aubín. [1576] 1963. U Historia de la nación mexicana - reproducción a todo color delCódice de 1576. Charles E. Dibble, ur. Madrid: Ediciones Porrua.

Fischer-Lichte, Erika. 2010. Povijest drame. Razdoblja identiteta u kazalištu od antike do danas, 1. Od anitke do njemačke klasike. Zagreb: Disput.

Gennep, Arnold van. 1960. The Rites of Passage. Chicago: University of Chicago Press.

Girard, René. 1990. Nasilje i sveto. Novi Sad: Književna zajednica Novoga Sada.

Grimes, Ronald L. 2014. Ritual Criticism. Case Studies in Its Practice, Essays on Its Theory. Waterloo: Ritual Studies International.

Horcasitas, Fernando. [1974] 2004. Teatro náhuatl I, épocas novohispana y moderna. México: Universidad Nacional Autónoma de México.

Domijan, Darija. Pojmovi: "obred”, "ritual”. 2012. Hrvatski opći leksikon. Klemenčić, Josip, ur. Zagreb: Leksikografski zavod Miroslav Krleža, 991, 1177.

Las Casas, Bartolomé de. [1502-1566] 1992. Apologética historia sumaria. Madrid: Alianza Editorial. 
León-Portilla, Miguel. [1959] 2004. Visión de los vencidos. Relaciones indígenas de la conquista. México: Universidad Autónoma de México.

Lozica, Ivan. 1990. Izvan teatra. Teatrabilni oblici folklora u Hrvatskoj. Zagreb: Hrvatsko društvo kazališnih kritičara i teatrologa.

Oxford Dictionary Online. Dostupno na: http://oxforddictionaries.com/ (pristup: 11. 9. 2014.).

Pavis, Patrice. 1987. Dictionnaire du théâtre. Paris: Editions Sociales.

Sahagún, Bernardino de. 1986. Coloquios y doctrina cristiana. México: Universidad Nacional, Autónoma de México.

Schechner, Richard. 2006. Performance Studies. An Introduction. New York: Routledge.

Torquemada, Juan de. [1615] 1995. Monarquía indiana. México: Universidad Nacional Autónoma de México.

Turner, Victor. 1982. Celebration. Studies in Festivity and Ritual. Washington, D.C.: Smithsonian Institution Press.

Turner, Victor. 1989. Od rituala do teatra. Ozbiljnost ljudske igre. Zagreb: August Cesarec.

Turner, Victor. 1997. The Ritual Process. Structure and Anti-Structure. New York: Aldine de Gruyter.

\title{
FROM THEATRE TO RITE: RITE RE-EVALUATION OF DRAMA ON THE EXAMPLE OF MISSIONARY THEATRE IN THE 16TH CENTURY MEXICO
}

\begin{abstract}
SUMMARY
The article analyses two cases of dramatic representation of the Spanish mysteries within the evangelization practice in the 16th century Mexico. The mysteries were originally designed as a vivid presentation of the Christian doctrine, but when incorporated in the Eucharist and rites like Baptism and Communion, they obtained sacred and rite significance. This work demonstrates and explains the process of dramatization and simultaneous realization of the rite, or rite revaluation of drama, using two examples of this custom within the evangelistic theatrical practice: the case of "performing Epiphany" and "performing Baptism" in the dance of Muslims and Christians. It is based on anthropological studies regarding performance characteristics of the religious rite and its liminality that stimulates the creation of new social and religious structures, and shows the impact of such rite-dramatic synergy in reforming religious identity among the Indian converts.
\end{abstract}

Key words: rite re-evaluation of drama, missionary theatre, Mexico, evangelization 